\title{
THE INFLUENCE OF CORPORATE GOVERNANCE AND PROFITABILITY ON THE CORPORATE SOCIAL RESPONSIBILITY DISCLOSURE: A STUDY AT MINING COMPANY LISTED ON INDONESIA STOCK EXCHANGE OVER THE PERIOD OF 2015-2016
}

\author{
Husaini Achmad, Supriono, Jayanti Karina Ries* \\ Faculty of Administrative Science, Brawijaya University, Malang \\ *E-mail: karinariesj@gmail.com
}

\begin{abstract}
This research aims to determine the influence of Good Corporate Governance or GCG (institutional ownership, board of commissioners' independence, board size) and profitability (ROE and ROA) on the CSR disclosure at a mining company in 2015-2016. The data was collected from ISE (Indonesia Stock Exchange). This was an explanatory research. The population of this research was 40 mining companies listed on ISE over the period 20152016, while the sample fulfilling criteria was 31 companies. The writers used a classical assumption test, multiple regression, and the coefficient of determination test as a data analysis. Some previous studies acknowledged that among GCG variables (institutional ownership, board of commissioners' independence, and board size) and profitability (ROE and ROA), a variable that influences is ROA, while the research result shows that ROA has no influence on CSR Disclosure.
\end{abstract}

\section{KEY WORDS}

Profitability, institutional ownership, board of commissioners, independence, board size.

The development of a company's business activity cannot be separated from the external environment, i.e. environment itself and community. A company has a responsibility to preserve the external environment that will not cause a negative impact, such as pollution and environmental deterioration. A company is expected to be able to balance between the operational activity followed by a concern on community welfare and sustainable environment.

A balanced relationship between company and stakeholders (environment and community) is something that should preserve to maintain a long-term continuing existence. A company has three public interests that tend to neglect in running its business, which is only paying attention the shareholder, the increase of negative impact on the environment, and community's difficulty to obtain recovery (Rudianto, 2013). One of the reasons of neglecting public interest is the low concern of the company towards the implementation of corporate social.

CSR is a company's commitment to giving assistance in the development of a sustainable economy in the aspect of the environment, social, and economy, Suhandari (in Untung, 2008). CSR implementation considered as an obligation which will raise company's periodical cost, but in a long-term period, social responsibility can bring a number of particular profits or benefits (Lako, 2011).

CSR initially considered as a burden will change into a strategic investment because it brings a permanent benefit for a company. The application of CSR in a company is not only the obligation of the internal party (company's leader and manager), but also all elements of a company are expected to contribute to realizing that goal. A company is expected able to apply corporate governance to keep the balance between the internal and external party.

Good Corporate Governance (GCG) is an instrument to make sure that management in a company runs well (Moeljono, 2005). GCG can be defined as a system that can regulate elements in a company to be more directed and controlled. GCH will boost transparency and accountability of a company so that can make s profit wholly for the community (Wahyudi, 2008). 
A company which considers the implementation of GCG as something important will have a health operational performance. Company's operational performance has a tight relationship with profitability. Profitability is defined as the efficiency and effectiveness of a company in increasing benefits in a particular time period (Munawir, 2010).

\section{LITERATURE REVIEW}

The implementation of GCG in a company focuses on the arrangement and processing of relationship of all parties synergic ally. GCG is a system and regulation about the relationship among parties in a company, which is shareholder and board of commissioners, and the role of board of directors to achieve company's goal (Wbisiono, 2007).

- Board Size. Board size variable covers all members that serve as a board of commissioners having a duty to supervise board of director in a company. Sembiring (as quoted in Sha, 2014).

- Institutional Ownership. Institutional ownership or stock ownership by an investor covers insurance company, bank, public limited company, etc., Tarjo (as quoted in Permanasari, 2010).

- Board of Commissioner's Independence. An independent commissioner or board of commissioners' independence in a company is a party having no business or relationship interest with the company, controlling shareholders, director members, and commissioner members. KNKG (as quoted in Aini, 2011).

Profitability rate can determine the success of a company. Profitability is an aspect to measure the efficiency and effectiveness in generating profits (Mardyantom 2008).

- Return on Assets is a ratio to measure a company's performance effectiveness with the basis of income and total assets owned (Syamsuddin, 2011).

- ROE ratio is used as a measurement of income received from the capital that has been invested previously (Syamsuddin, 2011).

A company is not an economic institution making profits only but also a social institution and part of the surrounding area. A company needs to do social contact with society so that able to act as an economic agent, agent of change, and agent of renewal (Lako, 2011).

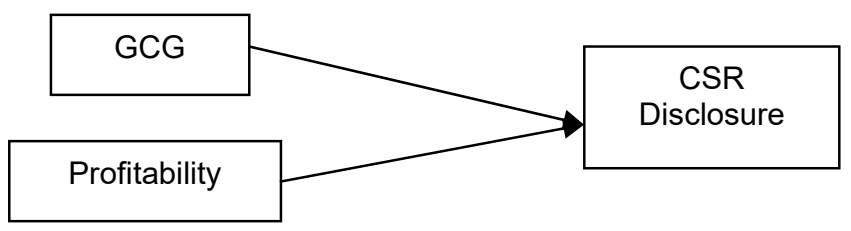

Figure 1 - Conceptual Model (Source: Data processed, 2017)

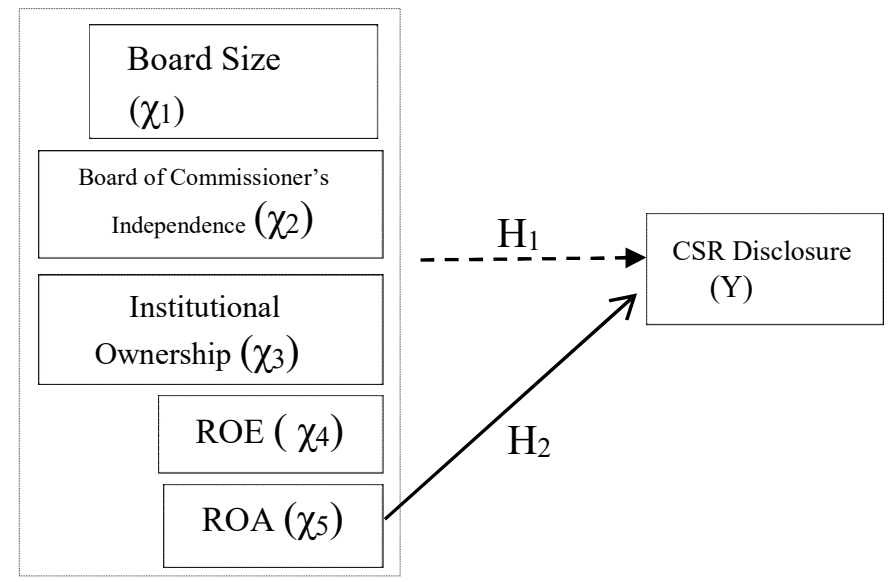

Figure 2 - Research Hypothesis (Source: Data processed 2017) 
CSR is not only limited to the economic responsibility about how a company maximizes profits, but also taking a social responsibility and environmental responsibility (Lako, 2011). A company has to balance between economic responsibility and social responsibility so will generate quality profits or socially or environmentally-friendly profits (green profit) as well as grow and develop sustainably (sustainable corporation) (Lako, 2011).

The hypothesis of this research is as follows:

- Variable $\mathrm{X} 1, \mathrm{X} 2, \mathrm{X} 3, \mathrm{X} 4$, and $\mathrm{X} 5$ are expected to jointly have an influence on variable Y;

- Variable $\mathrm{X} 5$ is expected to have the most dominant influence on variable $\mathrm{Y}$.

\section{METHODS OF RESEARCH}

This was an explanatory research. An explanatory method is a method that discloses the relationship of a variable with another variable in a research (Sugiyono, 2008). This research aims to explain whether each variable has an interest each other or not. In order to analyze the data, this research used the SPSS program. The sample of this research is a company fulfilling the criteria by 31 companies.

\section{RESULTS AND DISCUSSION}

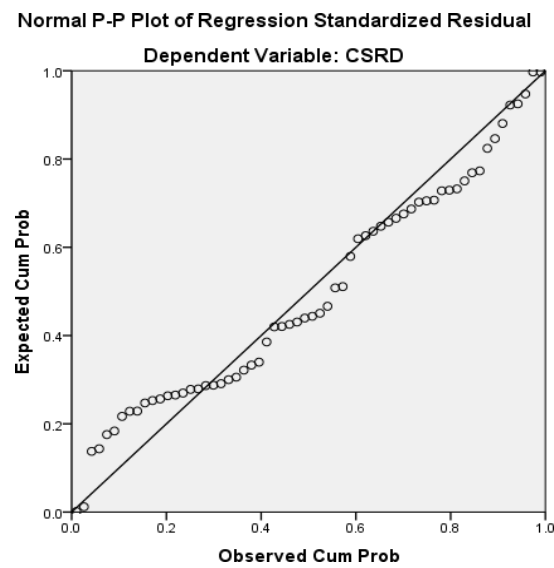

Figure 3 - P-Plot Graphics (Source: Data processed, 2017)

P-Plot graphics in figure 3 shows that the data has been distributed normally, with a pattern that approaches normal and its distribution is around the diagonal line.

Table 1 - Run Test

\begin{tabular}{|c|c|c|c|}
\hline \multicolumn{3}{|l|}{$\mathrm{n} / \mathrm{n}$} & Unstandarddized Residual \\
\hline \multicolumn{3}{|l|}{ Test Valuea } & -.01859 \\
\hline \multicolumn{3}{|l|}{ Cases < Test Value } & 31 \\
\hline \multicolumn{3}{|l|}{ Cases $>=$ Test Value } & 31 \\
\hline \multicolumn{3}{|l|}{ Total Cases } & 62 \\
\hline \multicolumn{3}{|l|}{ Number of Runs } & 30 \\
\hline \multicolumn{3}{|l|}{$\bar{Z}$} & -.512 \\
\hline \multicolumn{3}{|l|}{ Asymp. Sig. (2-tailed) } & .608 \\
\hline \multirow{3}{*}{$\begin{array}{l}\text { Monte Carlo Sig. (2- } \\
\text { tailed) }\end{array}$} & \multicolumn{2}{|l|}{ Sig. } & $.702 b$ \\
\hline & \multirow{2}{*}{$\begin{array}{l}99 \% \\
\text { Confidence Interval }\end{array}$} & Lower Bound & .690 \\
\hline & & Upper Bound & .714 \\
\hline \multicolumn{4}{|l|}{ a. Median } \\
\hline \multicolumn{4}{|c|}{$\begin{array}{l}\text { b. Based on } 10000 \text { sampled tables with starting seed } \\
1314643744 \text {. }\end{array}$} \\
\hline
\end{tabular}

Source: Data processed 2017.

The result of Run Test shows the amount of test value by -0.01859 with a probability of 
0.702. The test result states that the probability value is higher than the determined significance value $(0.702>0.05)$ so that the research data is free of autocorrelation.

Table 2 - Multicollinearity Test

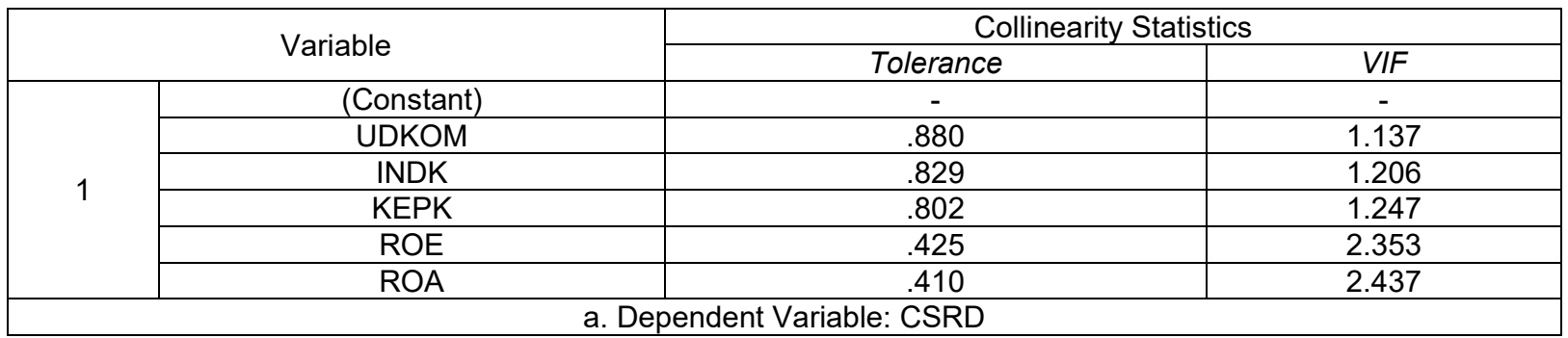

Source: Data processed 2017.

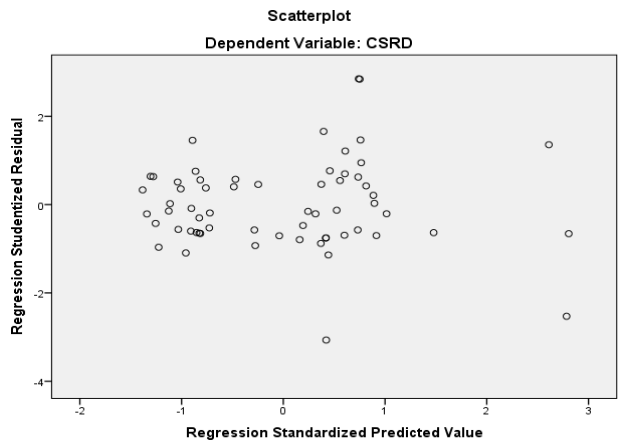

Figure 4 - Heteroscedasticity Test Result (Source: Data processed, 2017)

The result of heteroscedasticity testing at figure 4 shows that the points from the variable spread unequally and do not create pattern clearly above and under 0 at $Y$ axis. The testing result in figure 4 shows there is no heteroscedasticity.

Table 3 - Regression equation

\begin{tabular}{|c|c|c|}
\hline \multicolumn{2}{|c|}{ Model } & Unstandardized Coefficients \\
\cline { 2 - 3 } \multicolumn{4}{c|}{} & (Constant) & B \\
\cline { 2 - 4 } & UDKOM & .251 \\
\cline { 2 - 3 } & INDK & .034 \\
\cline { 2 - 3 } & KEPK & .087 \\
\cline { 2 - 3 } & ROE & -.039 \\
\cline { 2 - 3 } & ROA & -.056 \\
\hline \multicolumn{2}{|c|}{} & .135 \\
\hline
\end{tabular}

Source: Data processed 2017.

Interpretation of that equation:

- Board Size (Ukuran Dewan Komisaris or EDKOM) Diversification will increase of 0.034 units for every one unit increase of Board Size (X1). The escalation of one unit of board size will increase of $0.040(4 \%)$ with the assumption that other variables are constant.

- Board of Commissioners' Independency (Independensi Dewan Komisaris or INDK) Diversification will increase of 0.087 units for every addition of one unit of Board of Commissioners (X2). The increase of one unit board of commissioners' independence will have an impact of increase of $0.087(8.7 \%)$ with the assumption that other variables are considered constant.

- Institutional Ownership (Kepemilikan Institusional or KEPK) Diversification will decrease of 0.039 units for every addition of one unit of Institutional Ownership (X3). The increase of one unit institutional ownership will have an impact on increase of 
$0.039(4 \%)$ with the assumption that other variables are considered constant.

- Return of Equity (ROE). Diversification will have a decrease of 0.056 units for every addition of one unit Return of Equity (X4). The increase of one unit return of equity will cause a decrease of $0.056(5.6 \%)$ with the assumption that other variables are considered constant.

- Return of Assets (ROA). Diversification will increase of 0.135 units for every addition of one unit Return of Assets (X5). The increase of one unit return of assets will increase of $0.135(14 \%)$ with the assumption that other variables are considered constant. The Coefficient of Determination Test

Table 4 - The Coefficient of Determination Test

\begin{tabular}{|l|c|}
\hline \multicolumn{1}{|c|}{ Model } & \multicolumn{1}{|c|}{ R Square } \\
\hline \multicolumn{1}{|c|}{1} & \multicolumn{1}{|c|}{} \\
\hline $\begin{array}{l}\text { a. Predictors: (Constant), ROA, UDKOM, } \\
\text { KEPK, INDK, ROE }\end{array}$ \\
\hline b. Dependent Variable: CSRD \\
\hline
\end{tabular}

Source: Data processed 2017.

Table 4 indicates $\mathrm{R}$ square result by $0.213(21.3 \%)$. The research result reveals that dependent variable (CSR) will be influenced by independent variables (Board Size or UDKOM), Board of Commissioners' Independence (INDK), Institutional ownership (KEPK), ROE, and ROA by $0.213(21.3 \%)$,

While the remaining is by $78.7 \%$ will be influenced by other variables outside the study conducted by the writer.

Table 5 - F-test Result (Simultaneous Influence Test)

\begin{tabular}{|c|c|c|}
\hline \multicolumn{2}{|c|}{ Model } & F \\
\hline \multicolumn{1}{|c|}{ Megression } & 3.030 \\
\hline \multirow{3}{*}{1} & Residual & 1.141 \\
\cline { 2 - 3 } & Total & \\
\cline { 2 - 3 } & \multicolumn{1}{|c|}{$\begin{array}{c}\text { a. Dependent Variable: CSRD } \\
\text { b. Predictors: (Constant), ROA, UDKOM, KEPK, INDK, ROE }\end{array}$} \\
\hline
\end{tabular}

Source: Data processed 2017.

The result of simultaneous influence test in table $5, F_{\text {count }}$ shows 3.030 , while $F_{\text {table }}$ at the Percentage Point of Distribution $F$ for Probability df1=5; df2=62 indicates 2.36 . The result of F-test (simultaneous influence test) states that $F_{\text {count }}$ by 3.020 is bigger than $F_{\text {table }}$ by 2.36 $\left(f_{\text {count }}>F_{\text {table, }}\right.$ so that $\left.3.030>2.36\right)$, thus board size $(X 1)$, board of commissioners independence (X2), institutional ownership (X3), ROE (X4), and ROA (X5) have a joint influence on CSR disclosure.

Table 6 - T-test Result (Partial Influence Test)

\begin{tabular}{|c|c|c|}
\hline \multicolumn{2}{|c|}{ Model } & $\mathrm{t}$ \\
\hline \multirow{4}{*}{1} & (Constant) & 2.341 \\
\cline { 2 - 3 } & UDKOM & 3.510 \\
\cline { 2 - 3 } & INDK & .662 \\
\cline { 2 - 3 } & KEPK & -.351 \\
\cline { 2 - 3 } & ROE & -.607 \\
\cline { 2 - 3 } & ROA & .769 \\
\hline \multicolumn{2}{|c|}{ a. Dependent Variable: CSRD } \\
\hline
\end{tabular}

Source: Data processed 2017.

UDKOM (Board Size). The result of UDKOM test and CSR disclosure is indicated with $t_{\text {count }}$ by 3.510 , while $t_{\text {table }}$ at the percentage Point of Distribution $t$ for probability with $\alpha=0.05$ and $n=62$ is 1.66980 . T-test result in table 6 shows $t_{\text {count }}>t_{\text {table, }}$ which is $3.510>1.66980$. The 
result of statistical $t$ test in table 6 shows that independent variable of UDKOM has no significant influence on dependent variable (CSRD or Corporate Social Responsibility Disclosure).

INDK (Board of Commissioners" Independence). The result of t-test INDK and CSRD are stated with $t_{\text {count }}$ by 0.662 , while the $t_{\text {table }}$ at the percentage point of Distribution $t$ with $\alpha=0.05$ and $n=62$ is 1.66980 . The result of $t$-test indicates $t_{\text {count }}<t_{\text {table, }}$, which is $0.662<$ 1.66980. The result of statistical t test in table 6 shows that independent variable of INDK has no significant influence on dependent variable (CSRD).

KEPK (Institutional Ownership). The result of KEPK t-test and CSR disclosure is shown by $t_{\text {count }}$ of -0.351 , while the $t_{\text {table }}$ at the Percentage Point of Distribution $t$ for Probability with $\alpha=0.05$ and $n=62$ is 1.66980 . The result of $t$-test in table 6 indicates that $t_{\text {count }}<t_{\text {table }}$, which is by $1.351<1.66980$. The result of $t$ statistical test in table 6 shows that independent variable of KEPK has no significant influence on dependent variable (CSRD).

ROE. The result of $t_{\text {test }}$ between ROE and CSR disclosure us state by $t_{\text {count }}$ of 0.607 , while $t_{\text {table }}$ at the Percentage Point of Distribution $t$ for Probability with $\alpha=0.05$ and $n=62$ is 1.66980. The result of $t$-test in table 6 shows that $t_{\text {coun }} t<t_{\text {table, }}$, which is $-0.607<1.66980$. The result of t-statistical test in table 6 shows that independent variables, which is ROE has no significant influence on dependent variable (CSRD).

ROA. The result of $t$-test between ROA and CSR disclosure is shown by $t_{\text {count }}$ of 0.769 , while $t_{\text {table }}$ at the Percentage Point of Distribution $t$ for Probability with $\alpha=0.05$ and $n=62$ is 1.66980 . The result of $t$-test in table 6 shows that $t_{\text {count }}<t_{\text {table }}$, which is by $0.769<1.66980$. The result of $t$ statistical test in table 6 shows that independent variable, which is ROA has no significant influence on dependent variable (CSRD).

\section{CONCLUSION}

Independent variables of this research (ROA, ROE, board of commissioners' independence, board size, and institutional ownership) have a significant influence jointly on CSRD.

Deriving from the research done previously, ROA is the most influential variable among independency variables of board of commissioners, board size, institutional ownership, ROE and ROA, while the research result in Chapter IV shows that ROA has no influence on CSRD.

\section{SUGGESTIONS}

A mining company should include detail of CSRD in a sustainable report or annual report.

A further study is expected able to use more supporting variables to find a new standard model of a company's CSR disclosure forecasting.

A further study is expected to enlarge the observation period that will more help possibility in obtaining a real condition.

\section{REFERENCES}

1. Lako, A. (2011). Dokontruksi CSR \& Reformasi Paradigma Bisnis \& Akuntamsi. Jakarta: Erlangga.

2. Mardiyanto, H. (2008). Inti Sari Manajemen Keuangan. Jakarta: Grasindo.

3. Moeljono, D. (2005). Good Corporate Culture sebagai Inti Good Corporate Governance. Jakarta: PT Gramedia.

4. Munawir, S. (2010). Analisa Laporan Keuangan. Yogyakarta: Liberty.

5. Rusdianto, U. (2013). CSR Communications A Framework for PR Practitioners. Yogyakarta: Graha Ilmu.

6. Syamsuddin, L. (2011). Manajemen Keuangan Perusahaan. Jakarta: Rajawali Pers.

7. Untung, H. B. (2008). Corporate Social Responsibility. Jakarta: Sinar Grafika. 
8. Wahyudi, I., and Busyra, A. 2008. Corporate Social Responsibility. Malang: Setara Press dan Inspire Indonesia.

9. Wibisono, Y. (2007). Membedah Konsep \& Aplikasi CSR. Gresik: Fascho Publishing.

10. Sha, T. L. (2014). Pengaruh Ukuran Perusahaan, Ukuran Dewan Komisaris, Profitabilitas, dan Leverage terhadap Pengungkapan Tanggung Jawab Sosial (Studi pada Perusahaan Manufaktur yang Terdaftar di BEI). Jurnal Akuntansi, 18(1). 20-27.

11. Aini, N. N. (2011). Pengaruh Karakteristik Good Corporate Governance (GCG) terhadap Pengungkapan Corporate Social Responsibility (CSR) (Studi Empiris pada Perusahaan Non Keuangan yang Terdaftar di Bursa Efek). Semarang: Universitas Diponegoro.

12. Permanasari, W. I. (2010). Pengaruh Kepemilikan Manajemen, Kepemilikan Institusional, dan Corporate Social Responsibility terhadap Nilai Perusahaan (Unpublished Thesis). Universitas Diponegoro, Semarang. 